\title{
Downregulation of miR-30c-5p Expression in Colorectal Cancer Tissue is Sex-Dependent
}

\author{
Iveta HERICHOVA ${ }^{1 *}$, Richard REIS ${ }^{2} *$, Kristína HASAKOVA ${ }^{1}$, Marián VICIAN $^{\mathbf{3}}$ \\ * These authors contributed equally to this work. \\ ${ }^{1}$ Department of Animal Physiology and Ethology, Faculty of Natural Sciences, Comenius \\ University, Bratislava, Slovak Republic, ${ }^{2}$ First Surgery Department, University Hospital, Comenius \\ University Bratislava, Bratislava, Slovak Republic, ${ }^{3}$ Fourth Surgery Department, University \\ Hospital, Comenius University Bratislava, Bratislava, Slovak Republic
}

Received March 17, 2020

Accepted October 6, 2020

\begin{abstract}
Summary
We report that decreased expression of miR-30c in tumor compared to adjacent tissue is sex-dependent in colorectal cancer (CRC) patients. High expression of miR-30c was associated with better survival in the whole cohort. When the cohort was split into male and female subcohorts, decreased miR-30c expression in tumor compared to adjacent tissue was observed only in males. Expression of miR-30c was decreased in CRC tumor tissue in male patients with nodes involvement compared to those without metastases in nodes and this difference was not observe in females. Next dependency of miR-30c expression on oestrogen receptor $\beta$ (ER $\beta$ ) mRNA levels in tumor was tested. In males with low expression of $E R \beta$, we observed a significant decrease in miR-30c levels in patients with nodes involvement compared to those without nodes involvement. This difference was not observed in males with high ER $\beta$ mRNA levels and in females. Accordingly, males with low expression of $E R \beta$ and high expression of miR-30c showed a better survival that those with low expression ER $\beta$ and low expression of miR-30c. It is possible to conclude that whole cohort survival dependence on miR-30c is mostly generated by a subcohort of males with low expression of ER $\beta$ mRNA in tumor tissue.
\end{abstract}

\section{Key words}

Oestrogen receptor $\beta \bullet$ Males • Females • Metastases • Survival

\section{Corresponding author}

I. Herichova, Department of Animal Physiology and Ethology, Faculty of Natural Sciences, Comenius University Bratislava,
Ilkovicova 6, 84215 Bratislava, Slovak Republic. E-mail: herichova1@uniba.sk

\section{Introduction}

Colorectal cancer (CRC) is recently the fourth leading cause of cancer-related death worldwide (Bray et al. 2018). According SEER (2010-2016) a proportion of patients diagnosed with CRC surviving at least 5 -years is $65.6 \%$ in the USA. With this survival CRC takes $10^{\text {th }}$ position in the list of 24 malignant cancers after mesothelioma, pancreas, liver, oesophagus, lung, stomach, brain, and ovary cancers, and myeloma. Based on information provided by cancer registries of Australia, Canada, Denmark, Ireland, New Zealand, Norway, and the UK 5-years survival of CRC patients shows continual improvement from $60 \%$ during the period 1995-1999 up to $70 \%$ in years 2010-2014 (Arnold et al. 2019). In spite of obvious advances in CRC management, there is still acute demand for tools useful in determination of patient exact diagnosis and prognosis. In this respect miRNAs are frequently studied to assess cancer progression (Dave et al. 2019).

miR-30c-5p (miR-30) belongs to a large family of small noncoding miRNAs. Today approximately 1900 miRNAs were identified in the human genome and their number probably will be growing (Griffiths-Jones 2004, Li and Kowdley 2012). miRNAs are extensively studied because of their role in gene silencing. Based on the complementarity of miRNA seed sequence and

PHYSIOLOGICAL RESEARCH • ISSN 1802-9973 (online) 
3'-untranslated regions of mRNA miRNA in cooperation with argonaute protein, endonuclease dicer and other components create RNA-induced silencing complex (RISC) that targets mRNA. Complete RISC assures degradation and/or translation inhibition of complementary mRNA (Slack and Chinnaiyan 2019).

miR-30c usually exerts an oncostatic role, although some exceptions have also been shown (Yang et al. 2017). In the gastrointestinal tract, the tumor suppressive influence of miR-30c was demonstrated in several experimental models (Strubberg and Madison 2017). In human colon carcinoma cell line Caco-2 miR-30c regulates expression of KRAS that is involved in cancer development via epidermal growth factor (Nakayama et al. 2017). In LOVO and WE480 CRC cell lines, miR-30c downregulation of BCL9 (B cell lymphoma 9) expression has been shown. BCL9 exerts proliferative influence and over-expression in several malignancies (Zhao et al. 2019). In the stable gastric cancer cell line MGC-803 miR-30c downregulated metastasis-associated protein 1 (MTA1) that is strongly associated with tumorigenesis (Cao et al. 2017). miR-30c also inhibited expression of ADAM19 in HTC116 human colon cancer cells. ADAM19 is involved in a variety of pathologies including promotion of colon cancer cells invasiveness (Zhang et al. 2015).

The downregulation of miR-30c in cancer tissue compared to adjacent tissue is documented in breast, ovarian, endometrial, lung, gastric, and bladder cancers; neuroblastomas, mesotheliomas, and renal cell carcinomas (Irani and Hussain 2015, Kong et al. 2014, Han et al. 2020). Moreover, a decreased expression of miR-30c in malignant tissue has also been observed in patients suffering from colorectal cancer (Zhao et al. 2019, Zhang et al. 2015). On the basis of this knowledge, miR-30c has been suggested as a potential biomarker (Han et al. 2020).

Even though miR-30c is usually downregulated in tumor tissue compared to adjacent tissue (Irani and Hussain 2015), there are two studies that have implicated increased levels of miR-30c in the circulation of CRC patients compared to healthy control (Ostenfeld et al. 2016, Jacob et al. 2017). This observation can be explained by the secretion of oncostatic miRNAs from cancer cells as a disposal route of tumor suppressive elements (Ostenfeld et al. 2016).

In our previous studies (Hasakova et al. 2017, Hasakova et al. 2019), we investigated sex-dependent differences in miRNAs levels in CRC tumor tissue compared to adjacent tissues dependent on clinicopathological features. In this respect our attention turned to possible influence of oestrogen on CRC progression (Herichova et al. 2019).

Oestrogen exerts most of its effect via nuclear oestrogen receptors $\alpha$ and $\beta$ (ER $\alpha$ and $\operatorname{ER} \beta$, respectively) than influence gene transcription via oestrogen-response element (ERE). ER $\beta$ is predominant form of oestrogen receptor in the bowel. Except of genomic action, oestrogen receptors can also influence gene expression by indirect genomic signaling via protein-protein interactions with other transcriptional factors and regulatory elements or by oestrogen independent mechanism (Fuentes and Silveyra 2019). We observed a significant decrease in ER $\beta$ expression dependent on staging in females that was not observed in male patients diagnosed with CRC. In males a pronounced decrease in ER $\beta$ expression compared to adjacent tissues was present already at the very early stage of disease (Herichova et al. 2019). ER $\beta$ is known for its inverse relationship with CRC staging and grading, presence of colorectal polyps and capacity to mediate a beneficial response for patients. Therefore, ER $\beta$ selective agonists are investigated in preclinical and clinical studies with promising results (Williams et al. 2016).

Since effect of oestrogen on miRNA expression in CRC experimental model was reported recently (He et al. 2012) we decided to elucidate if there is a sexdependent difference in miR-30c expression and correlate it with expression of ER $\beta$ that mediates oestrogen regulation in colorectum.

\section{Material and Methods}

The patient cohort consisting of 64 patients (averaged age 69 years, males $69 \pm 1.7$ years, females $69 \pm 2.8$ years) was described in Table 1. Samples of tumor tissue (C18-C20), proximal ( $\geq 10 \mathrm{~cm}$ from tumor) and distal tissues ( $\geq 2 \mathrm{~cm}$ from tumor) were collected during the surgery. Tissue samples were frozen into liquid nitrogen and stored under $-70{ }^{\circ} \mathrm{C}$ until mRNA and miRNA extraction. Surgery and histological examinations of samples were performed at the First Surgery Department of the Faculty of Medicine of Comenius University and the University Hospital Bratislava in Slovakia. An experimental protocol corresponding with Helsinki declaration was approved by the Ethics Committee of Comenius University and explained to each patient. All participants provided written informed consent. 
miRNA was isolated from $70 \mathrm{mg}$ of tissue using RNAzol according to the vendor's instructions (MRC, USA; protocol for isolation of large RNA and small RNA fractions). Before reverse transcription poly(A) tailing kit (Life Technologies, USA) was employed to polyadenylate $1 \mu \mathrm{g}$ of miRNA. Polyadenylated template (100 ng) was transcribed using ImProm-IITM reverse transcription kit (Promega, USA) and a primer attached a universal tag with sequence 5'-CAGGTCCAGTTT TTTTTTTTTTTTVN-3'to miRNAs to extend their sequence (Busk 2014). hsa-miR-30c-5p expression was measured by real-time polymerase chain reaction (PCR) using miScript SYBR green PCR kit (Qiagen, Germany) and the StepOnePlus ${ }^{\mathrm{TM}}$ real-time PCR system (Applied Biosystems, USA). Primers for miR-30c (MI0000254) measurement: sense, 5'-GCAGTGTAAACATCC TACACTCT-3'; antisense, 5'-TCCAGTTTTTTTTTT TTTTTGCTGA-3' were designed by software miRprimer (Busk 2014). Splitting of the cohort according to low and high mRNA oestrogen receptor $\beta$ (ER $\beta$ ) levels was based on median. ER $\beta$ mRNA expression was published in the previous study Herichova et al. (2019).

Real-time PCR conditions for miR-30c-5p measurement were: activation of hot-start polymerase at $95^{\circ} \mathrm{C}$ for $15 \mathrm{~min}$ followed by 35 cycles at $94^{\circ} \mathrm{C}$ for $15 \mathrm{~s}$, $55^{\circ} \mathrm{C}$ for $30 \mathrm{~s}$ and $72{ }^{\circ} \mathrm{C}$ for $30 \mathrm{~s}$. Melting curve analysis was used for validation of PCR product specificity. Nuclear RNA U6 was used for gene normalization. Measurement of U6 is described elsewhere (Herichova et al. 2019).

Table 1. Patient's gender, tumor location and clinicopathological characteristics.

\begin{tabular}{|c|c|c|c|c|c|c|c|}
\hline & & \multicolumn{2}{|c|}{ Females } & \multicolumn{2}{|c|}{ Males } & \multicolumn{2}{|c|}{ Sum } \\
\hline & & $\mathbf{n}$ & $\%$ & $\mathbf{n}$ & $\%$ & $\mathbf{n}$ & $\%$ \\
\hline Cohort & & 26 & 41 & 38 & 59 & 64 & 100.0 \\
\hline \multirow{2}{*}{ Tumor location } & Right-side & 14 & 22 & 11 & 17 & 25 & 39.1 \\
\hline & Left-side & 12 & 19 & 27 & 42 & 39 & 60.9 \\
\hline \multirow{3}{*}{ Grading stage } & G 1-1.5 & 5 & 8 & 7 & 11 & 12 & 18.8 \\
\hline & G $2-2.5$ & 20 & 31 & 29 & 45 & 49 & 76.6 \\
\hline & G3 & 1 & 2 & 2 & 3 & 3 & 4.7 \\
\hline \multirow{4}{*}{ Clinical stage } & I & 1 & 2 & 3 & 5 & 4 & 6.3 \\
\hline & IIA, IIB & 8 & 13 & 21 & 33 & 29 & 45.3 \\
\hline & IIIA, IIIB & 10 & 16 & 5 & 8 & 15 & 23.4 \\
\hline & IVA, IVB & 7 & 11 & 9 & 14 & 16 & 25.0 \\
\hline \multicolumn{8}{|l|}{ TNM classification } \\
\hline \multirow{3}{*}{ Primary tumor invasion } & $\mathrm{T} 1-\mathrm{T} 2$ & 1 & 2 & 3 & 5 & 4 & 6.3 \\
\hline & $\mathrm{T} 3$ & 20 & 31 & 28 & 44 & 48 & 75.0 \\
\hline & $\mathrm{T} 4$ & 5 & 8 & 7 & 11 & 12 & 18.8 \\
\hline \multirow{3}{*}{ Regional lymph node } & N0 & 10 & 16 & 25 & 39 & 35 & 54.7 \\
\hline & N1 & 6 & 9 & 7 & 11 & 13 & 20.3 \\
\hline & $\mathrm{N} 2$ & 10 & 16 & 6 & 9 & 16 & 25.0 \\
\hline \multirow{2}{*}{ Distant metastasis } & M0 & 19 & 30 & 29 & 45 & 48 & 75.0 \\
\hline & M1 & 7 & 11 & 9 & 14 & 16 & 25.0 \\
\hline
\end{tabular}

$\mathrm{n}=$ number, $\mathrm{T}=$ tumor invasion, $\mathrm{N}=$ nodal status, $\mathrm{M}=$ distant metastasis; right-sided colon cancers include $\mathrm{C} 18.0-\mathrm{C} 18.4$, left-sided $\mathrm{CRCS}$ include C18.5-C20.

\section{Statistical analysis}

Evaluation of overall survival was performed by Kaplan-Meier survival curves followed by a log-rank testing related to the median miR-30c expression. The starting point for the log-rank test was the day when surgery was performed. Expression of miR-30c in cancer and adjacent tissues was compared by paired $t$-test. Expression of miR-30c between two clusters of patients 
was compared by unpaired $t$-test. Association between miR-30c expression and clinicopathological stages of patients was analysed by regression analysis. Data in histograms were provided as a mean \pm standard error of the mean (SEM). The level of significance was set at $p<0.05$.

\section{Results}

Expression of miR-30c in the whole cohort was significantly decreased in tumor compared to adjacent tissues (Fig. 1A; $p=1.2 * 10^{-4}$, paired $t$-test). High expression of miR-30c was associated with better survival and low miR-30c levels corresponded with worse survival in the whole cohort of patients (Fig. 1B; $p=0.045$, log-rank test).

miR-30c expression in cancer and adjacent tissues exerted sex-dependent differences. While miR-30c expression in males showed a pronounced decrease in tumor tissue compared to adjacent tissue (Fig. 2A; $p=0.001$, paired $t$-test), in females this difference achieved a borderline only level of significance (Fig. 2A; $p=0.051$, paired $t$-test). Expression of miR-30c in adjacent tissue of males was significantly higher compared to females ( $p=0.015$, unpaired $t$-test). The difference in miR-30c expression in the tumor tissue between the two genders did not achieve a level of significance ( $p=0.09$, unpaired $t$-test). When subcohorts of males and females were split according to presence of metastases in nodes, there was a significant difference in miR-30c expression in the tumor tissue depending on nodes metastases in males (Fig. 2B; $p=0.044$, unpaired $t$-test) while this difference was not observed in females.
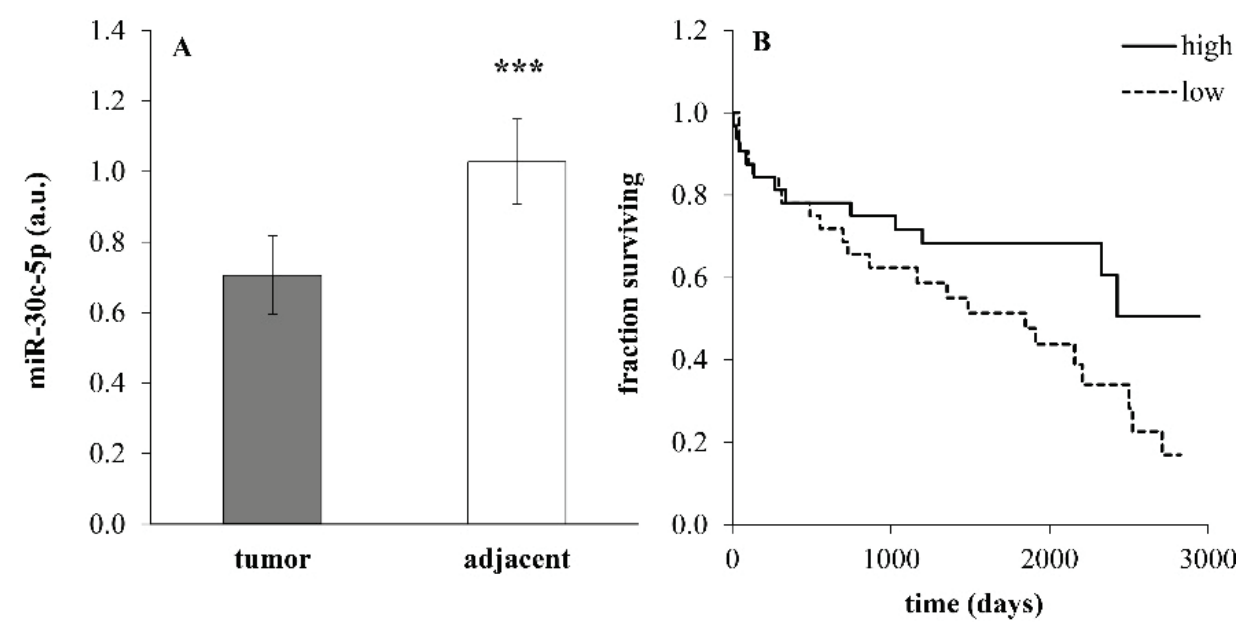

Fig. 1. Expression of miR-30c (A) in tumor and adjacent tissues in the whole cohort of patients $(n=64)$ undergoing surgery because of colorectal carcinoma. Data were provided as mean $\pm \mathrm{SEM}$. $* * * p<0.001$ (paired $t$-test). Expression in adjacent tissue was calculated as an average of expression in the healthy tissues sampled proximally and distally from the tumor (a.u.=arbitrary units). (B) Kaplan-Meier survival curves for the entire cohort of patients with low miR-30a expression ( $\leq$ median, dotted line) and high miR-30c expression (>median, solid line) in tumor tissue. $p=0.045$ (log-rank test).
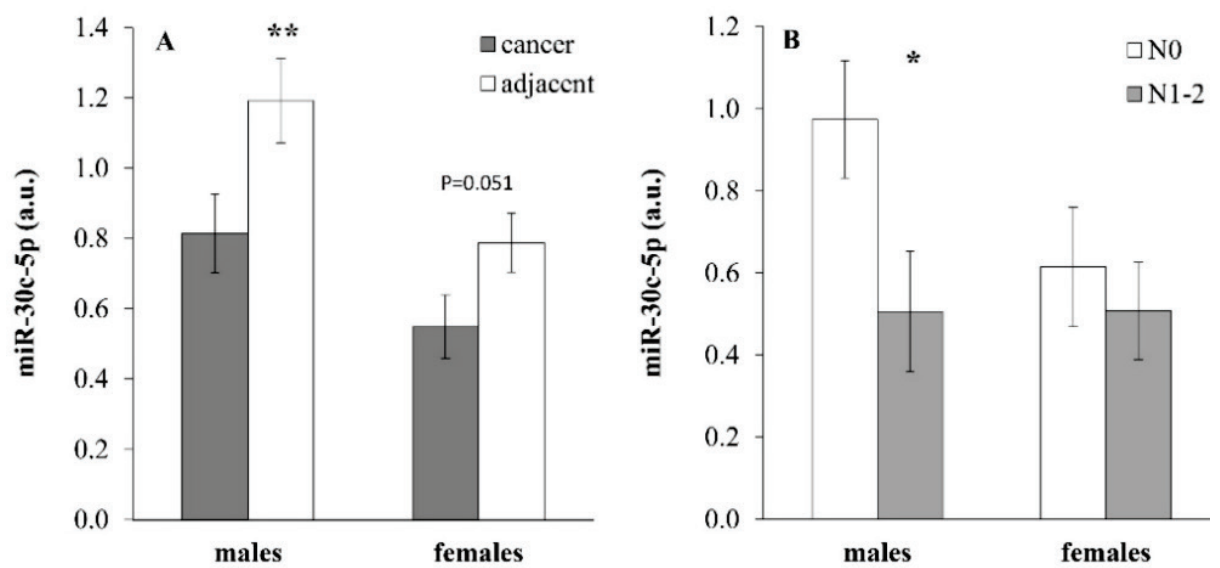

Fig. 2. Expression of miR-30c $(\mathbf{A})$ in tumor and adjacent tissues in male $(n=38)$ and female $(n=26)$ patients with colorectal cancer. Data are provided as mean $\pm \mathrm{SEM}$. ${ }^{* *} p<0.01$ (paired $t$-test). (B) miR-30c expression in tumor tissue of males and females with or without metastases in nodes $(\mathrm{n}=10-25)$. N0=without metastases in nodes, $\mathrm{N} 1-2=$ with metastases in nodes. $* p<0.05$ (unpaired $t$-test). 
Next, we evaluated the dependence of miR-30c on ER $\beta$ mRNA expression. In male subcohort with low ER $\beta$ expression in tumor miR-30c levels showed a significant difference between samples from patients without metastases in nodes compared to those with nodes involvement (Fig. 3A; $p=0.014$, unpaired $t$-test). This difference was not observed in males with high levels of ER $\beta$ mRNA in tumor (Fig. 3C) and in females (data not shown). Accordingly, males with low expression of ER $\beta$ mRNA exerted significant association between miR-30c expression and survival. High miR-30c expression in males with low ER $\beta$ was associated with better survival and low miR-30c expression was linked to worse survival (Fig. 3B; $p=0.017$, log-rank test). This dependence was not observed in males with high ER $\beta$ mRNA expression (Fig. 3D) and females.

Gender and ER $\beta$ dependent associations between miR-30c expression and clinicopathological parameters of patients are provided in Table 2. We observed a significant regression between miR-30c expression and nodes involvement, presence of distant metastases, grading and clinical stage in male patients with low ER $\beta$ expression. These correlations were not observed in female patients and males with high ER $\beta$ expression. Therefore, it is possible to conclude that survival dependence on miR-30c expression (Fig. 1B) is mostly generated by the subcohort of males with low expression of ER $\beta$ mRNA in tumor tissue (Table 2).
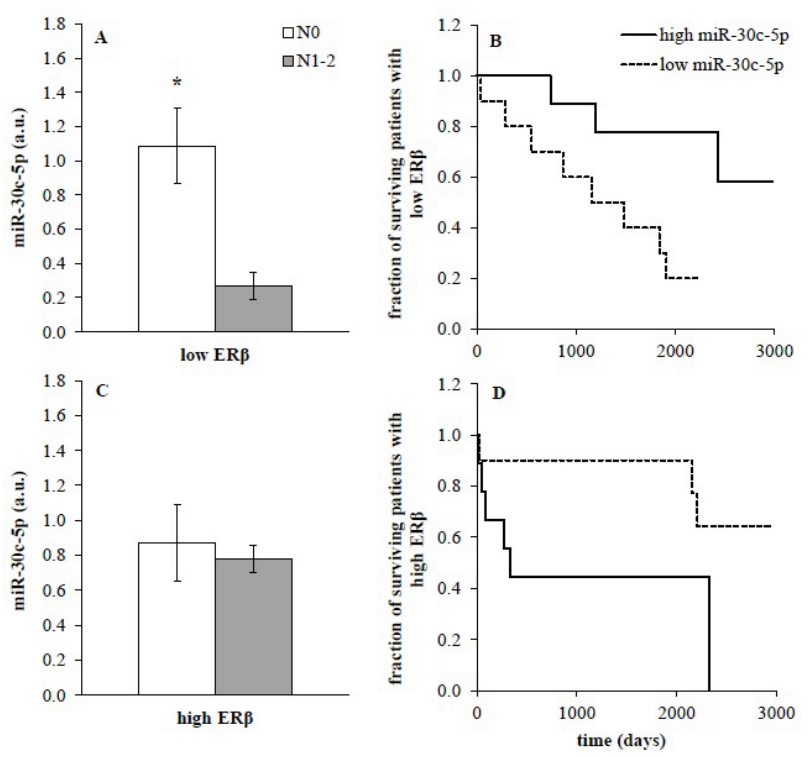

Fig. 3. miR-30c expression $(\mathbf{A}, \mathbf{C})$ in male subcohort split according to low $(n=9, \mathbf{A})$ or high $(n=19, \mathbf{C})$ expression of oestrogen receptor $\beta$ (ER $\beta$ ). Data were provided as mean \pm SEM. Low ER $\beta-$ expression of $E R \beta \leq$ median, high $E R \beta$ - expression>median; $\mathrm{N} 0=$ without metastases in nodes, N1-2=with metastases in nodes; $* p<0.05$ (unpaired $t$-test). (B, D) Kaplan-Meier survival curves for the male subcohort of patients with low (B) and high (D) ER $\beta$ expression were calculated in relation to low miR-30c expression ( $\leq$ median, dotted line, $p=0.017$, log-rank test) and high miR-30c expression (>median, solid line) in tumor tissue.

Table 2. The association between miR-30c expression, ER $\beta$ expression and clinicopathological stage of patients.

\begin{tabular}{|c|c|c|c|c|c|c|c|c|}
\hline \multirow{2}{*}{\multicolumn{3}{|c|}{ miR-30c-5p expression (a.u.) }} & \multicolumn{5}{|c|}{ Regression analysis } & \multirow{2}{*}{$\frac{\text { Log-rank test }}{\text { Survival }}$} \\
\hline & & & $\mathbf{T}$ & $\mathbf{N}$ & M & Grading & $\begin{array}{c}\text { Clinical } \\
\text { stage }\end{array}$ & \\
\hline \multirow{6}{*}{ Females } & \multirow{3}{*}{$\begin{array}{l}\text { low } \\
\text { ER } \beta\end{array}$} & beta & 0.128 & 0.054 & 0.212 & -0.129 & 0.163 & $n / a$ \\
\hline & & $\mathrm{R}$ & 0.125 & 0.069 & 0.212 & -0.129 & 0.205 & $n / a$ \\
\hline & & $p$ & ns & ns & ns & ns & ns & ns \\
\hline & \multirow{3}{*}{$\begin{array}{l}\text { high } \\
\text { ER } \beta\end{array}$} & beta & 0.263 & -0.140 & -0.050 & -0.215 & -0.052 & $n / a$ \\
\hline & & $\mathrm{R}$ & 0.345 & -0.290 & -0.033 & -0.244 & -0.095 & $n / a$ \\
\hline & & $p$ & $\mathrm{~ns}$ & ns & $\mathrm{ns}$ & ns & $\mathrm{ns}$ & ns \\
\hline \multirow{6}{*}{ Males } & \multirow{3}{*}{$\begin{array}{l}\text { low } \\
\text { ER } \beta\end{array}$} & beta & -0.185 & -0.479 & -0.802 & -0.775 & -0.337 & $n / a$ \\
\hline & & $\mathrm{R}$ & -0.253 & -0.547 & -0.522 & -0.493 & -0.465 & $n / a$ \\
\hline & & $p$ & ns & 0.015 & 0.022 & 0.032 & 0.045 & 0.006 \\
\hline & \multirow{3}{*}{$\begin{array}{l}\text { high } \\
\text { ER } \beta\end{array}$} & beta & 0.377 & -0.088 & 0.583 & 0.212 & 0.172 & $n / a$ \\
\hline & & $\mathrm{R}$ & 0.367 & -0.093 & 0.333 & 0.135 & 0.237 & $n / a$ \\
\hline & & $p$ & ns & ns & ns & ns & ns & ns \\
\hline
\end{tabular}

$T=$ tumor invasion, $N=$ nodal status, $M=$ distant metastasis, $E R \beta=$ oestrogen receptor $\beta$, beta=slope of the regression line, $R=$ regression coefficient, $\mathrm{ns}=$ not significant, $p=$ probability value, a.u. $=$ arbitrary units, $\mathrm{n} / \mathrm{a}=$ not applicable. 


\section{Discussion}

Our study showed that expression of miR-30c exerts sex-dependent expression in patients with CRC. We observed a significant downregulation of miR-30c expression in tumor tissue compared to adjacent tissue, and better survival associated with high miR-30c expression. This observation is in good agreement with previous findings (Zhang et al. 2015, Zhao et al. 2019). When the cohort was split according to gender and ER $\beta$ expression, it became obvious that difference observed at the level of the whole cohort was generated mostly by the male subcohort exerting low expression of ER $\beta$ (Table 2).

In our previous studies, we demonstrated sexdependent differences in miRNA-21, miR-16 and miR-34a expression in the colorectal tumor tissue (Hasakova et al. 2017, Hasakova et al. 2019). When we directly compared miR-30c expression between male and female patients, there was only a nonsignificant trend to increased levels in males compared to females in the tumor tissue. However, when the cohort was split according to nodes involvement, a difference between the two genders became obvious. Correlation analysis also indicates that miR-30c expression depends on the TNM stage much more in males compared to females. Sex-dependent differences in miRNAs expression have also been observed by other authors (Guo et al. 2017, Cui et al. 2018); however, an explanation for this finding is not readily available.

Since plasma concentration of oestrogen is similar in males and females at this age (Ober et al. 2008) we focused on the regulation of ER $\beta$ in CRC patients. Expression of ER $\beta$ is much more abundant in the gastrointestinal tract compared to ER $\alpha$ and the most of oestrogen effects in this tissue are expected to be mediated via ER $\beta$ (Fuentes and Silveyra 2019). ER $\beta$ executes its function mainly through ERE influencing transcription of oestrogen target genes (Deroo et al. 2010). There are two miR-30c encoding genes and both are located within intron of other gene. In the case of the intronic position of miRNA, miRNA is frequently transcribed together with the host gene (Baskerville and Bartel 2005, Pidikova et al. 2020).

miR-30c-1 gene is located in the intron of abundantly expressed nuclear transcription factor $\mathrm{Y}$ subunit C (NFYC) (Gurtner et al. 2017). However, full transcriptome analysis of ER $\alpha$ and ER $\beta$ mediated gene regulation did not reveal presence of ERE binding site in its sequence (Wiliams et al. 2008). Moreover, NFYC was shown to be up-regulated in $\mathrm{CRC}$ and its high expression was associated with worse survival of patients (Kottorou et al. 2012). Therefore, NFYC does not seem to be a key factor in determination of miR-30c expression.

miR-30c-2 is found in the intron of long noncoding RNA LINC00472 (C6orf155, P53RRA) that does not produce a protein (Irani and Hussain 2015). Unlikely NFYC, LINC00472 possess functional ERE site that via ER $\alpha$ induces LINC00472 expression (Wang et al. 2019). Activation of ERE located in LINC00472 by ER $\beta$ was not tested in CRC tissue yet. LINC00472 is, similarly like miR-30c, considered to be tumor-suppressor in CRC and shows decreased expression in CRC tumor tissue compared to adjacent tissue (Ye et al. 2018).

In our previous study (Herichova et al. 2019), we observed sex-dependent differences in ER $\beta$ expression in tumor tissue of CRC patients. While the expression of ER $\beta$ mRNA showed a decrease dependent on the TNM stage in females, in males, a decrease in ER $\beta$ expression was observed already at the very early stage of disease without nodes involvement. It is very likely that a decrease in ER $\beta$ expression in males occurs even before or during cancer onset. Therefore, it is possible that the ER $\beta$ and gender dependent miR-30c expression can be attributed to changed oestrogen signaling via ER $\beta$ receptors in early stages of CRC.

Although this assumption needs to be tested, it is in according with experiments implicating that miRNA expression is responsive to oestradiol (E2). E2 induced miR-30c expression in MCF-7 (Bhat-Nakshatri et al. 2009). On the other hand, it was reported, that $\mathrm{E} 2$ downregulated miR-30c expression in Ishikawa and HEC-1-B cells (Kong et al. 2014) and transcription of the whole set of miRNAs was inhibited in MCF-7 cell line after E2 treatment (Mailot et al. 2009). In colon adenocarcinoma COLO205 cell line E2 induced expression of ER $\beta$ and inhibited expression of several miRNAs. There results were partially confirmed in human cohort ( $\mathrm{He}$ et al. 2012).

Taken together, miR-30c exerts decreased levels in tumor tissue compared to adjacent tissue in patients diagnosed with CRC, and low levels of miR-30c are associated with worse survival. Expression of miR-30c is more related to the TNM status in males, especially in those with low expression of ER $\beta$ compared to females, which is also reflected by the survival curves. Males with low expression of ER $\beta$ and high expression of miR-30c show better survival than other clusters of the cohort. This finding is in accordance with previously observed sex-dependent differences in ER $\beta$ expression in CRC 
between males and females, and the inhibitory effect of oestrogen on miRNAs expression. We propose that subclustering of the clinical cohort can significantly contribute to personalized medicine and can help to more precisely depict which group of patients generates differences observed at the level of the whole cohort.

\section{Conflict of Interest}

There is no conflict of interest.

\section{Acknowledgements}

Research was supported by grants APVV-16-0209, APVV-14-0318 and VEGA 1/0679/19.

\section{References}

ARNOLD M, RUTHERFORD MJ, BARDOT A, FERLAY J, ANDERSSON TM, MYKLEBUST TÅ, TERVONEN H, THURSFIELD V, RANSOM D, SHACK L, WOODS RR, TURNER D, LEONFELLNER S, RYAN S, SAINTJACQUES N, DE P, MCCLURE C, RAMANAKUMAR AV, STUART-PANKO H, ENGHOLM G, ET AL.: Progress in cancer survival, mortality, and incidence in seven high-income countries 1995-2014 (ICBP SURVMARK-2): a population-based study. Lancet Oncol 20: 1493-1505, 2019. https://doi.org/10.1016/S14702045(19)30456-5

BASKERVILLE S, BARTEL DP: Microarray profiling of microRNAs reveals frequent coexpression with neighboring miRNAs and host genes. RNA 11: 241-247, 2005. https://doi.org/10.1261/rna.7240905

BHAT-NAKSHATRI P, WANG G, COLLINS NR, THOMSON MJ, GEISTLINGER TR, CARROLL JS, BROWN M, HAMMOND S, SROUR EF, LIU Y, NAKSHATRI H: Estradiol-regulated microRNAs control estradiol response in breast cancer cells. Nucleic Acids Res 37: 4850-4861, 2009. https://doi.org/10.1093/nar/gkp500

BRAY F, FERLAY J, SOERJOMATARAM I, SIEGEL RL, TORRE LA, JEMAL A: Global cancer statistics 2018: GLOBOCAN estimates of incidence and mortality worldwide for 36 cancers in 185 countries. CA Cancer J Clin 68: 394-424, 2018. https://doi.org/10.3322/caac.21492

BUSK PK: A tool for design of primers for microRNA-specific quantitative RT-qPCR. BMC Bioinformatics 15: 29, 2014. https://doi.org/10.1186/1471-2105-15-29

CAO JM, LI GZ, HAN M, XU HL, HUANG KM: MiR-30c-5p suppresses migration, invasion and epithelial to mesenchymal transition of gastric cancer via targeting MTA1. Biomed Pharmacother 93: 554-560, 2017. https://doi.org/10.1016/j.biopha.2017.06.084

CUI C, YANG W, SHI J, ZHOU Y, YANG J, CUI Q, ZHOU Y: Identification and analysis of human sex-biased microRNAs. Genomics Proteomics Bioinformatics 6: 200-211, 2018. https://doi.org/10.1016/j.gpb.2018.03.004

DAVE VP, NGO TA, PERNESTIG AK, TILEVIK D, KANT K, NGUYEN T, WOLFF A, BANG DD: MicroRNA amplification and detection technologies: opportunities and challenges for point of care diagnostics. Lab Invest 99: 452-469, 2019. https://doi.org/10.1038/s41374-018-0143-3

DEROO BJ, BUENSUCESO AV: Minireview: Estrogen receptor-beta: mechanistic insights from recent studies. Mol Endocrinol 24: 1703-1714, 2010. https://doi.org/10.1210/me.2009-0288

FUENTES N, SILVEYRA P: Estrogen receptor signaling mechanisms. Adv Protein Chem Struct Biol 116: 135-170, 2019. https://doi.org/10.1016/bs.apcsb.2019.01.001

GRIFFITHS-JONES S: The microRNA registry. Nucleic Acids Res J32 (Database issue): D109-D111, 2004. https://doi.org/10.1093/nar/gkh023

GURTNER A, MANNI I, PIAGGIO G: NF-Y in cancer: Impact on cell transformation of a gene essential for proliferation. Biochim Biophys Acta Gene Regul Mech 1860: 604-616, 2017. https://doi.org/10.1016/j.bbagrm.2016.12.005

GUO L, ZHANG Q, MA X, WANG J, LIANG T: miRNA and mRNA expression analysis reveals potential sex-biased miRNA expression. Sci Rep 7: 39812, 2017. https://doi.org/10.1038/srep39812

HAN W, CUI H, LIANG J, SU X: Role of MicroRNA-30c in cancer progression. J Cancer 11: 2593-2601, 2020. https://doi.org/10.7150/jca.38449

HASÁKOVÁ K, BEZAKOVA J, VICIAN M, REIS R, ZEMAN M, HERICHOVA I: Gender-dependent expression of leading and passenger strand of miR-21 and miR-16 inhuman colorectal cancer and adjacent colonic tissues. Physiol Res 66 (Suppl 4): S575-S582, 2017. https://doi.org/10.33549/physiolres.933808 
HASAKOVA K, REIS R, VICIAN M, ZEMAN M, HERICHOVA I: Expression of miR-34a-5pis up-regulated in human colorectal cancer and correlates with survival and clock gene PER2 expression. PLoS One 14: e0224396, 2019. https://doi.org/10.1371/journal.pone.0224396

HE YQ, SHENG JQ, LING XL, FU L, JIN P, YEN L, RAO J: Estradiol regulates miR-135b and mismatch repair gene expressions via estrogen receptor- $\beta$ in colorectal cells. Exp Mol Med 44: 723-732, 2012. https://doi.org/10.3858/emm.2012.44.12.079

HERICHOVA I, REIS R, HASAKOVA K, VICIAN M, ZEMAN M: Sex-dependent regulation of estrogen receptor beta in human colorectal cancer tissue and its relationship with clock genes and VEGF-A expression. Physiol Res 68 (Suppl 3): S297-S305, 2019. https://doi.org/10.33549/physiolres.934352

IRANI S, HUSSAIN MM: Role of microRNA-30c in lipid metabolism, adipogenesis, cardiac remodeling and cancer. Curr Opin Lipidol 26: 139-146, 2015. https://doi.org/10.1097/MOL.0000000000000162

JACOB H, STANISAVLJEVIC L, STORLI KE, HESTETUN KE, DAHL O, MYKLEBUST MP: Identification of a sixteen-microRNA signature as prognostic biomarker for stageII and III colon cancer. Oncotarget 8: 87837-87847, 2017. https://doi.org/10.18632/oncotarget.21237

KONG X, XU X, YAN Y, GUO F, LI J, HU Y, ZHOU H, XUN Q: Estrogen regulates the tumour suppressor MiRNA-30c and its target gene, MTA-1, in endometrial cancer. PLoS One 9: e90810, 2014. https://doi.org/10.1371/journal.pone.0090810

KOTTOROU AE, ANTONACOPOULOU AG, DIMITRAKOPOULOS FI, TSAMANDAS AC, SCOPA CD, PETSAS T, KALOFONOS HP: Altered expression of NFY-C and RORA in colorectal adenocarcinomas. Acta Histochem 114: 553-561, 2012. https://doi.org/10.1016/j.acthis.2011.10.005

LI Y, KOWDLEY KV: MicroRNAs in common human diseases. Genomics Proteomics Bioinformatics 10: 246-253, 2012. https://doi.org/10.1016/j.gpb.2012.07.005

MAILLOT G, LACROIX-TRIKI M, PIERREDON S, GRATADOU L, SCHMIDT S, BÉNÈS V, ROCHÉ H, DALENC F, AUBOEUF D, MILLEVOI S, VAGNER S: Widespread estrogen-dependent repression of micrornas involved in breast tumor cell growth. Cancer Res 69: 8332-8340, 2009. https://doi.org/10.1158/0008-5472.CAN-09-2206

NAKAYAMA T, FUNAKOSHI-TAGO M, TAMURA H: Coffee reduces KRAS expression in Caco-2 human colon carcinoma cells via regulation of miRNAs. Oncol Lett 14: 1109-1114, 2017. https://doi.org/10.3892/ol.2017.6227

OBER C, LOISEL DA, GILAD Y: Sex-specific genetic architecture of human disease. Nat Rev Genet 9: 911-922, 2008. https://doi.org/10.1038/nrg2415

OSTENFELD MS, JENSEN SG, JEPPESEN DK, CHRISTENSEN LL, THORSEN SB, STENVANG J,HVAM ML, THOMSEN A, MOURITZEN P, RASMUSSEN MH, NIELSEN HJ, ØRNTOFT TF, ANDERSENCL: miRNA profiling of circulating $\operatorname{EpCAM}(+)$ extracellular vesicles: promising biomarkers of colorectal cancer. J Extracell Vesicles 5: 31488, 2016. https://doi.org/10.3402/jev.v5.31488

PIDÍKOVA P, REIS R, HERICHOVA I: miRNA clusters with down-regulated expression in human colorectal cancer and their regulation. Int J Mol Sci 21: 4633, 2020. https://doi.org/10.3390/ijms21134633

SLACK FJ, CHINNAIYAN AM: The role of non-coding RNAs in oncology. Cell 179: 1033-1055, 2019. https://doi.org/10.1016/j.cell.2019.10.017

STRUBBERG AM, MADISON BB: MicroRNAs in the etiology of colorectal cancer: pathways and clinical implications. Dis Model Mech 10: 197-214, 2017. https://doi.org/10.1242/dmm.027441

WANG Z, KATSAROS D, BIGLIA N, SHEN Y, LOO L, YU X, LIN H, FU Y, CHU WM, FEI P, NI Y, JIA W, DENG X, QIAN B, YU H: ER $\alpha$ upregulates the expression of long non-coding RNA LINC00472 which suppresses the phosphorylation of NF-אB in breast cancer. Breast Cancer Res Treat 175: 353-368, 2019. https://doi.org/10.1007/s10549-018-05108-5

WILLIAMS C, EDVARDSSON K, LEWANDOWSKI SA, STRÖM A, GUSTAFSSON JA: A genome-wide study of the repressive effects of estrogen receptor beta on estrogen receptor alpha signaling in breast cancer cells. Oncogene 27: 1019-1032, 2008. https://doi.org/10.1038/sj.onc.1210712

WILLIAMS C, DILEO A, NIV Y, GUSTAFSSON JÅ: Estrogen receptor beta as target for colorectal cancer prevention. Cancer Lett 372: 48-56, 2016. https://doi.org/10.1016/j.canlet.2015.12.009 
YANG SJ, YANG SY, WANG DD, CHEN X, SHEN HY, ZHANG XH, ZHONG SL, TANG JH, ZHAO JH: The miR-30 family: Versatile players in breast cancer. Tumour Biol 39: 1010428317692204, 2017. https://doi.org/10.1177/1010428317692204

YE Y, YANG S, HAN Y, SUN J, XV L, WU L, WANG Y, MING L: Linc00472 suppresses proliferation and promotes apoptosis through elevating PDCD4 expression by sponging miR-196a in colorectal cancer. Aging 10: 1523-1533, 2018. https://doi.org/10.18632/aging.101488

ZHAO DW, LI MM, HAN JP, WANG Y, JIANG LX, CHANG HL: MiR-30c exerts tumor suppressive functions in colorectal carcinoma by directly targeting BCL9. Eur Rev Med Pharmacol Sci 23: 3335-3343, 2019. https://doi.org/10.26355/eurrev_201904_17696

ZHANG Q, YU L, QIN D, HUANG R, JIANG X, ZOU C, TANG Q, CHEN Y, WANG G, WANG X, GAO X: Role of microRNA-30c targeting ADAM19 in colorectal cancer. PLoS One 10: e0120698, 2015. https://doi.org/10.1371/journal.pone.0120698 